\title{
Moderating Effect of Career on Women Online Shopping Behaviour in South-South, Nigeria
}

\author{
Titus Chukwuemezie Okeke \\ Nnamdi Azikiwe University, Awka, Nigeria. \\ Philomena Uzezi Omodafe \\ Delta State Polytechnic Ogwashiuku, Delta State, Nigeria \\ Greg Amaechi Ezeh \\ Abubakar Tafawa Balewa University, Bauchi, Nigeria.
}

\author{
Basil Chibuike Nwatu \\ Department of Marketing, Enugu State University of Science and Technology \\ Enugu, Enugu State, Nigeria
}

\begin{abstract}
The study examined the moderating effect of career on women online shopping behaviour. Data for the study were gathered from 330 career women in South-South, Nigeria through structured questionnaire. The study explored five constructs and evaluated a proposed model explaining the moderating effect of career and the relationship between them. SPSS version 25 was used for preliminary analysis while WarpPLS 7.0 was used in testing the hypothesized relationships. The findings revealed that career moderates the influence of perceived risk, perceived usefulness, performance expectancy and internet selfefficacy in online shopping behaviour among career women while social influence is partially supported and validated from the analysis. The study concludes that the proposed model would serve as a relevant theory that will be helpful in understanding the adoption decisions of career women in working and shopping environments. The study recommends that continuous patronage of online shops by career women can only be guaranteed with improvements in online shopping sites in order to attract and increase traffic to them.
\end{abstract}

Keywords: Online shopping, South-South, Women, Career, Telecommunication, Diffusion of Innovation.

\section{INTRODUCTION}

Online shopping is the act of purchasing products over the Internet. It is a form of electronic commerce which allows customers to buy products from an online shop from the comfort of their homes and/or offices (Okeke, 2017). This a development that follow from the explosion in information and communication technology (ICT) and its wide application in marketing. The International Telecommunication Union annual report of 2015 represented a global overview of 
Okeke, T. C., Omodafe, P. U., Ezeh, G. A., \& Nwatu, B. C. (2020). Moderating Effect of Career on Women Online Shopping Behaviour in South-South, Nigeria. Archives of Business Research, 8(5). 143-164.

the latest developments in ICT and reflected the continuous evolvement of the global information society in developed and developing countries. The report also reveals that, globally, $46 \%$ of men and $41 \%$ of women are Internet users (TDB report, 2015). Thus, despite the long held orthodoxy that the Internet cannot be used in the developing world in the same way it is used in the highly developed nations, recent events are indicating rather forcefully that the Internet has emerged as one of the transforming inventions that will have serious impact on the social, political and economic relations of $21^{\text {st }}$ century Africa and beyond (Nkamnebe, 2017). Hence, online shopping is unleashing great potentials in releasing the locked vibrancy in career women as they purchase variety of products from the comfort of their homes (Monsuwe, Dellaert \& Ruyter, 2004). As Shagaya (Founder of Konga, Nigeria) (2013) astutely stated "online shopping is the new cool not just in Nigeria but in the world over". He further stated that "retail here is still mostly informal, fragmented and inefficient as the sector is still struggling to get it right; though, the Nigerian consumers want convenience, which gives us the opportunity to leapfrog with e-commerce". According to Nielsen (2010), shopping online is most under-developed in the Middle East, Africa and Pakistan region. However, with Nigeria in the seventh position among the top ten countries in the world starting from China (Internet World Stat, 2017); it is a proof of the hunger of the emerging middle class in which the empowered females in Nigeria are part and parcel of the revolution. Today, Nigeria is one of the fastest growing internet markets in Africa with triple-digits growth rate almost every single year since 2001 (Internet World Stats, 2017).

In the traditional Nigerian society, women are usually imposed certain socio-culturally ascribed gender roles which arguably have entrenched a historical imbalance in power relationships between men and women (Odiaka, 2013). This socio-cultural structures and boundaries imposed by the dominatory male chauvinism made Nigeria gained the unpopular recognition globally as a Patriarchal society in which the woman is confined to home care and family purchasing roles. (Oniye, 2008; Ajayi, Ojo \& Mordi, 2015). However, with formal education and empowerment of various kinds that allowed some forms of liberation in recent years, the age-long restriction deliberately placed on women life choices, freedom of participation in paid jobs outside the home and where/how they buy is changing (Mordi, Simpson, Singh \& Okafor, 2010 and Ogbogu, 2013). The National Bureau of Statistics (2015) statistical report on men and women in Nigeria puts the labour force participation rate at $65.1 \%$ for women and $71.4 \%$ for men. The report states further that some measures of equity seem maintained between men and women in few states, 'women dominate the labour force in some states.' The South-South states belong to those states in Nigeria where either there is equity or the women dominate in the work force. With the $21^{\text {st }}$ century working women becoming more professional and career-oriented and less restricted in their professional pursuits, the need to consider the moderating effect of their online buying behaviour is imperative.

Different theories and models have been employed by researchers in studies of online shopping behaviour. These include the Davis (1989) Technology Acceptance Model (TAM); Zhou, Dai and Zhang (2007) Online Shopping Acceptance Model (OSAM); Venkatesh, Morris and Davis (2003) Unified Theory of Acceptance and Use of Technology (UTAUT) Model; Rogers (2003) diffusion of innovation theory. Lockett and Littler refined the innovation diffusion theory by adding perceived risk (see Kolodinsky, Hogarth and Hilgert, 2004). This study adopted some dimensions of these models/theories to form the models for the study. Hence from Davis (1989) we adopted perceived usefulness, from Venkatesh et al. is performance expectancy and social influence, from Zhou et al. 
(2007) is internet experience which we relate to internet self-efficacy, and from the refined innovation diffusion theory we adopted perceived risk. Accordingly the aim of this study is to ascertain how these dimensions affect women online shopping and whether career moderates the effects of the dimensions on the online shopping behaviour of women in South-South Nigeria.

\section{LITERATURE REVIEW}

\section{Nigerian Career Women and the task of Balancing Conflicting Roles}

In Nigeria, women constitute about half of the population and by extension half of the work force and remains a precious human resource of the nation. The total population in 2017 was estimated at 190,632,261 million people (population growth rate put at 3.28\% per annum) made up of $49.5 \%$ (94,654,572 million) females and 50.5\% (95,977,689 million) males (World Population Report (WPR) online, 2018). Globally, women's participation in the labour market varies greatly across countries reflecting differences in economic development, education levels, social norms and access to childcare and other support services. As per a latest ILO study "Women at work Trends 2016", the global female labour rate has decreased from 52.4 to 49.6. Hence worldwide, the chances for women to participate in the labour market remains $27 \%$ lower than those for men. In Nigeria, for the period 2010-2015, on the average, $72.3 \%$ of senior positions in the State Civil Service were occupied by men while $27.7 \%$ were occupied by women (NBS, 2015).

Without any doubt, one of the most significant socio-economic trends of the past three decades is the unprecedented increase in the number of Nigerian women in the labour force particularly that of women pursuing different careers and holding executive/management positions against all considerable odds in both the public and private sectors (Akaah, 1989; Alanana, 2004; Ugwu, Maduagwu \& Aginah, 2016 and NBS, 2015). Consequently, an important change in the lifestyle that has accompanied the working womanhood in contemporary years is the increasing sense of "lack of time" as most of them tend to be overwhelmed by the challenges of building and maintaining a career especially at the top management level; in addition to carrying the lion's share of domestic responsibilities (Christ, 2004; Oniye, 2008; Benco \& Pelster, 2013).

Arguably, women's career success is playing a significant role in marketing decisions in contemporary years as advancing and succeeding in the professional world is becoming increasingly challenging for career women especially those holding top managerial positions. According to Lussier (2006), career is a sequence of job related positions, involving increasing responsibilities/compensation and held over a life time. Also, in the views of Seema and Sujatha, (2018), career means the sum total of the various positions in a specified profession you may hold in your lifetime in which you gain advancement over a period of time. In the context of this study, career refers to the professional journey of top-level executive women in the public and private sectors through learning, work experience and life roles, involving increasing responsibilities/compensation and undertaken for a significant period of their lives. Thus, from a professional standpoint, career involves special training, formal education and working permanently in a specified profession for a significant period of time.

Career women as online retailing customers are believed to be highly engrossed in their official duties and should not have to take time to go to the store and buy goods; rather, the store goes to meet them (Monsuwe, Dellaert \& Ruyter, 2004). According to The Economist (2013), "Shops are to shopping as typewriters are to writing"; implying that mortar-and-brick shops are like an old 
Okeke, T. C., Omodafe, P. U., Ezeh, G. A., \& Nwatu, B. C. (2020). Moderating Effect of Career on Women Online Shopping Behaviour in South-South, Nigeria. Archives of Business Research, 8(5). 143-164.

technology, which is now doomed by a better successor - online shops. However, with contemporary marketing giving due importance to gender (feminine) studies, evidence from the literature suggests that there exists on one hand a heightened uncertainty and risk perception by women regarding online transactions; and on the other hand, there is a perceived added-value role of shopping online especially in balancing career/family conflicts, reducing stress associated with mortar-and-brick shopping method and also meeting the critical demands of the career job (Forsythe \& Shi, 2003; Zhou, Dai \& Zhang, 2007; Goswami \& Dutta, 2016 and Celik, 2016).

Over the years, marketers have shown serious concerns on the overall performance and wellbeing of career women with the recognition that most career women have clearly expanded their footprints in the managerial ranks and upper echelons of the society. Hence, from the early $19^{\text {th }}$ century when women got employed into paid jobs outside the home, technological innovation referred to as the white-goods technology was introduced to reduce roles conflicts and make working women derive the benefits of assuming multiple roles (Carrigan \& Szmigin, 2006; CoenPirani, Daniele \& León, Alexis \& Lugauer, 2010). Thus, for decades, researchers (Shove, 2003; Silverstein \& Sayre, 2009; and Benco \& Pelster, 2013) have sought to understand why most working women fail to reconcile ambitious career aspirations with family/other obligations. One of the reasons for the lack of equilibrium relates to the critical and essential responsibility of everyday shopping to meet personal, family and organizational needs in which perceived value of time, benefits, performance improvement, personal capability and level of risks involved are major considerations (Nicholas \& Fox, 1983; Ogbogu, 2013; Slide, 2017).

Interestingly, marketers have over the years tried to explore, understand and meet career women's peculiar needs faster, easier and better as they are a viable target market and major stakeholders in the development project of any society (Alanana, 2004; Ezzedeen \& Ritchey, 2009 and Kotler \& Keller, 2016). Until recently, the traditional method (offline or mortar-and-brick method) of shopping with its numerous challenges was the main channel of exchange of goods/services in Nigeria. Online shopping as a relatively new marketing medium has not been seen in most developing countries from the perspective of being adopted as an adaptation strategy but has been deployed effectively in different parts of the globe especially in developed countries (Catalyst, 2007; Ezzedeen \& Ritchey, 2009; Aghdaie, Piraman, Fathi, 2011; Ahmed, 2012 and Celik, 2016).

Moreover, with the recent widespread concerns about the corresponding need for women to secure their career and succeed in top managerial positions in both the public and private sectors, offering an easier and more convenient way to make daily purchases may result in improved job performance. Again, to the best of the researcher's knowledge, online shopping adoption studies have attracted little attention in Nigerian literature in recent years especially as it relates to adopting a more sustainable lifestyle for career women. Hence, the need for the study is urgent and relevant. Besides, as women's share in the Nigerian labour force continued to rise and the nature of their participation significantly changed with increasing responsibilities (Fakeye, George \& Owoyemi, 2012; Ajayi et al, 2015 and Obamiro, \& Obasan, 2013), it is imperative to empirically examine if career can moderate the influence of perceived risk, perceived usefulness, performance expectancy, internet self-efficacy and social influence of career women online shopping adoption decisions in South-South, Nigeria. 
In the views of Idemobi and Akam, (2012), a worrisome issue experienced by today's Nigerian employees is that they are constantly under the pressure of how to overcome challenges that militate against the realization of their ambitions and self-actualization especially as they advance in their chosen careers. For the working class women in particular, there are socio-cultural factors that make it harder for them to put forth the kind of efforts and dedication that gets individuals anointed for career advancement (Oniye, 2008). Studies have shown that women have a hard time finding eligible partners to begin with because their professional ambitions are generally not appealing to men (Hewlett, 2002; Christ, 2004; Catalyst, 2007). Also, for most working married women, the foundational career building years generally coincide with fertility, as they find themselves having to make choices that men do not experience. Again, although having children does not change their professional orientation (Korabik \& Rosin, 1995), African women are more likely than men to amend their careers in response to parenting in order to minimize negative effects on their family values as the blame of children failures most times goes to the women. Thus, subsequent absenteeism, low productivity and fewer years of quality job experience undercut their quick advancement and even growth in earnings (Eze, 2017).

Given that work-family research has its conceptual roots in role conflict theory (in Ezzedeen \& Ritchey (2009); much of it has focused on the conflict linkage whereby participation in one role is made more difficult by virtue of participation in another. Most basically, career and family can either hinder or facilitate each other. Nevertheless, there is growing awareness that facilitation can coexist with conflict in work/family relationships (Greenhaus \& Powell, 2006). This notion of facilitation is grounded on theories of role accumulation (in Ezzedeen \& Ritchey, 2009); which argue that individuals, especially women, derive benefits by engaging in multiple roles. Thus, in recent years, women have competing devotions especially as they tend to be facing serious conflicts in trying to maintain a satisfying level of equilibrium in their career and family lives, as on average, women still have more responsibility for home maintenance, family life and child care than men.

To achieve career/family balance therefore, working women particularly at the top management level who work for longer hours and highly engaged in their work schedules are expected to be fortified with modern technology to improve their overall performance and balance career-family conflicts. This includes how to conveniently, comfortably and timely embark on shopping without those distractions associated with mortar-and-brick method. Thus, seeking and adopting a wellstructured, timely and convenient shopping channel that engenders a more sustainable lifestyle and enhances overall performance tends to be critical for empowered female professionals in senior management positions (Nkamnebe, 2017; Slide, 2017 and Mordi, et al, 2010).

Also, in a study on Work-Family Balance and Coping Strategies among 730 women employees of purposively selected commercial banks by Ajayi, Ojo and Mordi (2015) in Lagos Metropolis and Ogun State, Nigeria, the influence of socio-demographic characteristics on work-family conflict experienced by women in the banking sector was found to be significant. Also, the study revealed that higher status workers are likely to work long hours and to be highly engaged in their work circumstances that may engender work-family conflict and reduce work-family fit. The analysis revealed that age brackets 30-39 and 40-49 years have negative relationship with the ability to balance work-family roles; that is, they are not able to balance work-family roles. These age categories fall within the reproductively active age group. This was found to be due to the earlier 
Okeke, T. C., Omodafe, P. U., Ezeh, G. A., \& Nwatu, B. C. (2020). Moderating Effect of Career on Women Online Shopping Behaviour in South-South, Nigeria. Archives of Business Research, 8(5). 143-164.

age brackets in which women will often have more family responsibilities to attend to due to a high level of workplace stress experienced in the Nigerian banking sector in addition to family role demand, which is usually very demanding for them resulting in their inability to balance up except when they adopt technology innovation strategies and support from spouse and paid domestic help. In a phenomenological study on the experiences of Nigerian women regarding challenges and strategies in management and leadership positions in relation to their domestic lives and responsibilities, and the experience of being both an executive and caretaker for a family, Eze (2017) found that the rapid shift from the Nigerian traditional cultural practices to a modernized Western practice has led to an exacerbation of role conflict for women entering the workforce.

The International Telecommunication Union annual report of 2015 represented a global overview of the latest developments in Information and Communication Technologies (ICTs) and reflected the continuous evolvement of the global information society in developed and developing countries. The report also reveals that, globally, $46 \%$ of men and $41 \%$ of women are Internet users (TDB report, 2015). Thus, despite the long held orthodoxy that the Internet cannot be used in the developing world in the same way it is used in the highly developed nations, recent events are indicating rather forcefully that the Internet has emerged as one of the transforming inventions that will have serious impact on the social, political and economic relations of $21^{\text {st }}$ century Africa and beyond (Nkamnebe, 2017). Hence, online shopping is unleashing great potentials in releasing the locked vibrancy in career women as they purchase variety of products from the comfort of their homes (Monsuwe, Dellaert \& Ruyter, 2004). As Shagaya (Founder of Konga, Nigeria) (2013) astutely stated "online shopping is the new cool not just in Nigeria but in the world over". He further stated that "retail here is still mostly informal, fragmented and inefficient as the sector is still struggling to get it right; though, the Nigerian consumers want convenience, which gives us the opportunity to leapfrog with e-commerce". According to Nielsen (2010), shopping online is most under-developed in the Middle East, Africa and Pakistan region. However, with Nigeria in the seventh position among the top ten countries in the world starting from China (Internet World Stat, 2017); it is a proof of the hunger of the emerging middle class in which the empowered females in Nigeria are part and parcel of the revolution. Today, Nigeria is one of the fastest growing internet markets in Africa with triple-digits growth rate almost every single year since 2001 (Internet World Stats, 2017). However, previous researches on the slow adoption of e-commerce in Nigeria resulting in the inability of online shopping to reach its full potentials have identified various contributing factors such as low conversion rates from browsers to purchasers, shortage of credible indigenous online vendors, perceived risk of cybercrime, privacy concerns, no structured way of presenting information to users, little assistance in helping customers find appropriate products, low internet penetration, lack of trust/security, nascent online payment system and infrastructure deficit (Gabriel, Ogbuigwe \& Ahiauzu, 2016; Okeke, 2017). Despite the aforementioned challenges facing the Nigerian Internet sector, it remains the largest in Africa valued at $\$ 13$ billion and growing at a rapid pace of $25 \%$ annually (Internet World Stat, 2017). It is therefore evident that Nigeria has a great potential of adopting online shopping; however, the aforementioned challenges need to be urgently addressed.

\section{Hypotheses}

\section{Perceived Risk (PR)}

Perceived risk is the consumers' perceived uncertainties in contemplating purchases of products or services. It refers to the nature and amount of risks perceived by a consumer in contemplating 
a particular purchase decision (Liebermann \& Stashevsky, 2002). According to Pavlou (2003), perceived risk is defined as the customers' subjective belief of suffering a loss in pursuit of a desired outcome. Before purchasing a product, a consumer considers the various risks associated with the purchase. The different types of risks are referred to as perceived or anticipated risks. From extant literature on online shopping, it is found that perceived risk has a stronger correlation with willingness to shop online than convenience (in Zhou, Dai \& Zhang, 2007). Also, as observed by Egwali, (2009), when the perceived risks experienced by the online consumer is high, he/she may shift to brick-and-mortar retailer for the purchase of the product. On the other hand, the lower the perceived risks, the higher the propensity for online transactions.

It is noteworthy that besides the risk of the possible misuse of credit card information and personal data. Thus, risks perceived or real may exist due to technology failure (e.g., breaches in the system) especially for developing countries or human error (e.g. data entry mistakes). In the views of Liebermann and Stashevsky (2002), perceived risk and insecurity are known to play important roles in the consumers' online shopping decision-making process. Hence, the level of uncertainty surrounding the online shopping process influences consumers' perceptions with respect to perceived risks (Bhatnagar et al., 2000). According to Garbarino and Strahilevitz (2004), women associate risk with their readiness to shop online, and that a negative result or experience of using the web would have severe implication on whether they would use this channel to shop again or not.

More so, Bartel-Sheehan (1999) identified that there may be a link between risk and privacy; as online women are concerned about the loss and invasion of privacy, the inability of physically seeing, feeling and touching the product first before purchase, the inability of seeing the transaction being processed, the handling of data concerned and what is happening with their details which add to their reservations and apprehensiveness. In addition, Okeke (2017) observed that Nigerians are very suspicious of buying online considering high levels of cybercrime in recent times. More so, the absence of strong infrastructure to support the online shopping process has been a major challenge. It is expected however that career of the online shopper moderates this feeling of uncertainty; hence, we provide a proposition as follows:

H1a.Perceived risk has significant influence on women online shopping adoption.

H1b. Career moderates the relationship between perceived risk and women online shopping adoption.

\section{Perceived Usefulness (PU)}

PU refers to the benefits of a technology such as online shopping and is one of the driving forces in its adoption process (Chen et al, 2002; Pavlou, 2003; Zhou, Dai \& Zhang, 2007). Moreover, a previous study on the correlation between PU and consumer behaviour revealed that perceived usefulness has significant effect towards online shopping behaviour in Spain but Aghdaie, Piraman and Fathi (2011) found that perceived usefulness do not have significant effect on internet purchasing behaviour in Iran. This could be due to differences in respondents standpoints from developed and developing countries regarding the perceived usefulness influence on their internet shopping behaviour. Thus, concerns of price, quality, durability and other product-related aspects are the main drivers of buying decision in developed countries but the considerations could vary from those of developing countries (Ahmed, 2012). According to Kim \& Song (2010), perceived usefulness was proven to have significant impact on the intention to purchase via internet. A 
Okeke, T. C., Omodafe, P. U., Ezeh, G. A., \& Nwatu, B. C. (2020). Moderating Effect of Career on Women Online Shopping Behaviour in South-South, Nigeria. Archives of Business Research, 8(5). 143-164.

supported study by Kim \& Song (2010) advocated that consumers expected to receive useful information and to browse through merchandise conveniently for purchase. Otherwise, the online shoppers will shift to their competitors since there are many similar products on sale in other online stores. According to Li et al. (1999), one key element of perceived usefulness of online shopping to consumers is in the convenience it provides while shopping as most consumers value convenience in shopping as their frequency of online shopping increases. They also identified other positive attributes in online shopping that tends to eliminate fear such as speed, perceived value (time and labour saving), efficiency and the perceived ease of use of the system. Again studies by Ezzedeen and Ritchey, (2009) and Carrigan and Szmigin, (2006), found that convenience of online shopping in terms of time and effort saving outweighs the inconveniences, especially when consumers are under time pressure or when the physical store is far away. A study on women's apparel shopping behaviour on the Internet by Hirst and Omar (2007) in India evaluated 192 women's attitude as an overall inclination towards apparel shopping online suggest that women generally show positive attitudes towards shopping online for apparel. Women who shop for apparel online are aware of some of the discouraging features of online shopping, but these features do not deter them from buying online. Convenience of time is particularly important for career women, hence we hypothesize that:

H2a.Perceived usefulness has significant influence on women online shopping adoption.

H2b. Career moderates the relationship between perceived usefulness and women online shopping adoption.

\section{Performance Expectancy (PE)}

Performance expectancy refers to the degree to which an individual believes that using the system would help him/her to attain gains in job performance (Venkatesh, et al, 2003). It is the influence of the consumer's belief that accepting and using online shopping innovation would help her achieve improvement in her overall performance. One of the challenges faced by today's working women while ascending and maintaining top management positions is how to meet family, career and personal needs faster, easier and better. Thus, in career development of working class women, their all-round performance is critical especially as they climb the ladder of leadership and also juggle conflicting priorities that are constantly making demands on their time. In a study by Ugwu et al. (2016), it was reported that the PE of most working women remains the driving force in enhancing their adoption of any innovation. PE suggests that individuals evaluate their technologymoderated task performances in terms of the associated benefits (i.e. facilitation of efficiency, effectiveness and productivity in task performance) and costs (i.e. cognitive, behavioural or financial investments made for special tasks) (Pereay Monsuwé et al., 2004). Likewise, Narasimhamurthy (2014) studied 450 young Indian adults and disclosed that females use social media as a productive tool but males use it as a means of entertainment. Again, in a study by Howcroft \& Wilson, (2003), they found that the household-workplace dyad of career women has challenged them to manage these two critical roles in a way that performance improvement is attained. Based upon this, we provide a proposition thus:

H3a.Performance expectancy has significant influence on women online shopping adoption. $H 3 b$. Career moderates the relationship between performance expectancy and women online shopping adoption. 


\section{Internet Self-efficacy (ISE)}

Wangpipatwong and Papasratorn (2007) see self-efficacy as people's judgments of their competencies to handle and execute courses of action required to attain designated types of performances. It is also referred to as the belief in one's ability to engage in specific actions that result in desired outcomes (Busch, 1995). Thus, self-efficacy is an online shopping terminology that helps to describe the ability of an individual to apply their Internet skills to complete a purchase online. It does not focus on the skills one has, but rather the judgments of what one can do with his or her skills. Bandura (1986) proposed a social cognitive theory known as Internet self-efficacy. He defined Internet self-efficacy as one's ability to effectively use the Internet. Internet self-efficacy therefore, relates to the level of technological competence of the user (woman). Internet selfefficacy is seen as "the belief in one's capability to organize and execute Internet actions required to produce given attainments. When extended to the World Wide Web (WWW) domain, Internet self-efficacy is not concerned only with the computer skill but also the Internet skill such as using e-mail, browsing the WWW, in self-services technology etc. Internet self-efficacy is defined as the belief that one can successfully perform a distinct set of behaviours required to establish, maintain and utilize effectively the Internet over basic personal computer skills (Eastin \& LaRose, 2000). Also, Kotler \& Keller (2016) have opined that an important characteristic for any adoption of an innovation takes place when the consumer's level of competence is high.

On the other hand, a situation wherein consumers are unmotivated to try new products or behaviours that they perceive as too difficult to adopt is known as low self-efficacy. Studies have found that the perceived cognitive and/or behavioural effort needed to learn and utilize an information technology artefact (personal innovativeness) directly influences adoption, especially in the exploratory period of technology use (Venkatesh \& Davis, 2000; Citrin, Sprott, Silverman \& Stem, 2000). In a study by Eastin and LaRose, (2000), they found that previous Internet experience is positively related to Internet self-efficacy. Also, He and Freeman (2010) revealed that males are generally found to have higher Internet skills than females and that user attitude and computer anxiety are both found influential to Internet self-efficacy while Celik (2015) observed that females tend to feel less comfortable with computing because they react more somatically to emotion and uncertainty; and thus are more reluctant to develop adequate computing self-efficiency. Also, Eastin (2002) found that user acceptance of online shopping is positively affected by a person's internet self-efficacy. Again, training is also found to be helpful in the improvement of learners' Internet self-efficacy, especially for those with higher attitudes toward computers, and those with low computer anxiety (Torkzadeh et al., 2006; Torkzadeh \& Van Dyke, 2002).In another study by Venkatesh et al. (2003), they revealed that females are more anxious than men when it comes to IT utilization and this nature of the females reduced their self-effectiveness which in turn led to increased perceptions of the effort required to use IT. This argument therefore leads us to the fourth hypothesis which states that:

H4a. Internet self-efficacy has significant influence on women online shopping adoption. H4b. Career moderates the relationship between Internet self-efficacy and women online shopping adoption.

\section{Social Influence (SI)}

Social influence is a construct that refers to conformity to social and normative reference group pressure. A reference group is referred to as an actual or imaginary group conceived of having 
Okeke, T. C., Omodafe, P. U., Ezeh, G. A., \& Nwatu, B. C. (2020). Moderating Effect of Career on Women Online Shopping Behaviour in South-South, Nigeria. Archives of Business Research, 8(5). 143-164.

significant relevance upon an individual's evaluations, aspiration or behaviour (Bhatnagar \& Ghose, 2004a). As Makgosa and Mohube (2007) rightly stated, there are people that an individual keeps in mind when making a purchase. Usually, such people disseminate opinions and other individuals are pressured into following their trend, becoming associated with them and using them as a standard of their purchase decision. As posited by Venkatesh et al., (2012), SI is an individual's perception that others think he/she should use an information technology artefact. They further stated that it is a consumer's susceptibility to reference group influence which comprises subjective norms, social factors and image constructs identified as conceptually similar and reflects the normative pressure involving an individual's persuasion of approval about technology use from his/her social group and motivation to comply with the shared social meaning of it among the group members. UTAUT, inheriting the common premise of theory of reasoned action and TPB, considers technology adoption as a volitional behaviour (see Ajzen, 1991). Thus, it suggests the deliberative intent mechanism in which social norm acts as a direct determinant of intention and intention mediates its relation with adoption behaviour. However, the regarded impact of normative pressure on focal behaviour has been the subject of much debate. While some argue that SI has a direct effect on technology adoption in mandatory settings due to compliance resulting from potential social rewards and punishments for engagement or no engagement in the technology use, others suggest that it has a direct effect on the personal beliefs on the technology in voluntary settings due to internalization and identification resulting from the personal desire to maintain a favourable image and gain social status within the reference group by using the technology (Venkatesh \& Davis, 2000; Venkatesh et al., 2003; Mazman, Usluel \& Çevik, 2009).

In a study by Lachance, Beaudion \& Robitaille (2003), it was found that reference groups influence product selection, information processing, attitude formation and shopping behaviour. Venkatesh et al. (2003) also found that females are more sensitive to the suggestions of the peers and hence the effect of social influence will be stronger when forming the intention to use Information Technology (IT) related services. A study by Setiffi (2014) revealed that adoption of innovation by consumers in the $21^{\text {st }}$ century is no longer about fulfilling needs; but that it is intertwined in social relations, identities, perceptions and images. More so, in the context of adopting technological innovation, Mazman, et al, (2009) revealed that females are more induced to adopt technological innovation through social influence rather than by a personal decision whereas in case of males, the personal decision to adopt innovation is much stronger than social influence. Based on these, we hypothesize that:

H5a. Social influence has significant influence on women online shopping adoption.

H5b. Career moderates the relationship between social influence and women online shopping adoption.

\section{Demographics and Data Collection}

\section{METHODOLOGY}

The unit of analysis for this study consists of career women in the six states that make up the SouthSouth geopolitical zone of Nigeria. The states are: Akwa Ibom, Cross River, Delta, Edo, Bayelsa and Rivers States. These states are known for their high literacy rates and attainment rates that are well above the national levels. According to the National Bureau of Statistics (2018) literacy rates for these states are: $93 \%, 89 \%, 87 \%, 91 \%, 87 \%$, and 96\% respectively. Also, according to Nigeria Infopaedia (2020) three of the South-South states: Rivers, Akwa Ibom, and Delta are listed among 
the 10 most educated states in Nigeria. These states are all within the Niger Delta Region hence have crude oil deposits and are all included in the oil mineral producing areas development commission (OMPADEC), now Niger Delta Development Commission (NDDC), hence have been affected negatively and positively by oil exploration activities in the region. Surveys through questionnaire were purposefully administered in the area to the career women that includes working class women with tertiary education qualification whether working in public or private sector. Self-employed women were also included but such a person must have tertiary education qualification. Accordingly, women in private practice like lawyers, accountants, medical doctors among others were included since we believe that with tertiary education a woman is more involved in her work/business and can therefore understand online shopping better as well as the import of the study to give optimised responses. In all 330 responses were obtained and our analysis was based on this captive sample. Most of the respondents, $57.7 \%$ are within their prime ages of 46 - 55 years of age, 10\% are under 35 years, $24.8 \%$ are within $35-45$ years, while $14.3 \%$ are above 55 years. Also majority of the career women in the South-South $62.7 \%$ are married, $14.3 \%$ are single, while $23 \%$ are either divorced or separated or widowed. On education, majority of $71.3 \%$ of the respondents have first degrees or equivalents, while $28.7 \%$ have post graduate qualifications. When asked their experiences, majority of $61.8 \%$ have between $19-25$ years of experience, $14.3 \%$ have been in their chosen career for more than 32 years, $12.1 \%$ have 12 - 18 years of experience while $11.8 \%$ have between 26 - 32 years of experience. This implies that majority of respondents have reasonable work experience to be included in the study.

\section{Measurement}

Six constructs were used in this study and each was measured with four items as sourced from extant literature. This study carefully crafted the items based on existing literature and adapted some dimensions of these models/theories to form the models for the study. Perceived usefulness was taken from Davis (1989); performance expectancy and social influence taken from Venkatesh et al. (2003); while internet experience/internet self-efficacy came from Zhou et al. (2007). Career is the moderating variable which was also measured impulsively in a metric manner like the five independent variables and the dependent variable. To reduce respondents fatigue that may arise from long list of questions, we used only items that are considered adequate for the constructs while at the same time avoiding over lengthy statements that may bore the respondents. More over all items were measured with five-point Likert scale $(1=$ strongly disagree; $2=$ agree; $3=$ undecided; 4 = agree; and 5 = strongly agree).

\section{Statistical Technique}

Partial least squares structural equations modelling (PLS-SEM) was utilised in estimation and validation of the hypotheses for this study. This is for a number of reasons. First is that Hair, Risher, Sarstedt, and Ringle's (2019) have established that PLS-SEM is preferable when estimating formative constructs or a mix of formative and reflective measures which is the situation in this paper. The second reason is that the PLS-SEM has been employed and used extensively by previous researchers and authors (Osakwe, 2019; Ibrahim \& Roni, 2017; and Okeke \& Nkamnebe, 2018) and has been established as an appropriate tool for analysis and estimation just like the covariancebased (CB-SEM) model (Hair, et al. 2019). The third reason for using the PLS-SEM is that as a nonparametric equivalent of SEM it makes less demand on data compared to the CB-SEM; however the PLS-SEM software used for the analysis is WarpPLS version 7.0, which brings together "the 
Okeke, T. C., Omodafe, P. U., Ezeh, G. A., \& Nwatu, B. C. (2020). Moderating Effect of Career on Women Online Shopping Behaviour in South-South, Nigeria. Archives of Business Research, 8(5). 143-164.

precision of CB-SEM algorithms under common factor model assumptions with the nonparametric characteristics of classic PLS algorithms" (Kock, 2020, p.6).

\section{Common Method Bias}

Common method bias (CMB) is usually associated with survey research where questionnaire like in this case is used to collect responses on both the independent and the dependent variables. Evidences abound that CMB influences item validities, reliabilities, and the covariation between latent constructs (MacKenzie \& Podsakoff, 2012). In view of this, research outcomes where method bias is serious cannot be relied upon as they could be misleading. Based on this, researchers take measures to address the issues that may generate serious concerns about CMB. There are qualitative and quantitative measures for addressing issues of CMB. On the qualitative aspect and based on the instructions of Podsakoff, MacKenzie, Lee, and Podsakoff, (2003), we stated in the latter part of the questionnaire that there are no right or wrong answers. Respondents were also assured of anonymity and that their responses are for academic purposes only. Quantitatively, we conducted the Harman's one-factor test (see Podsakoff, et al. 2003, Jakobsen, 2015) using exploratory factor analysis (EFA). The result of the EFA show that no single factor account for majority of the variances hence CMB is not a major issue in our study. We used PLS-SEM to test our hypotheses and Kock $(2020,2015)$ recommend using full collinearity VIF to check CMB (table 3.1).

Table 3.1: Full collinearity VIF

\begin{tabular}{|c|c|c|c|c|c|c|}
\hline $\begin{array}{l}\text { Perceive } \\
\text { d risk }\end{array}$ & $\begin{array}{l}\text { Perceive } \\
\mathrm{d} \\
\text { usefulne } \\
\text { ss }\end{array}$ & $\begin{array}{l}\text { Performan } \\
\text { ce } \\
\text { expectancy }\end{array}$ & $\begin{array}{l}\text { Internet } \\
\text { self- } \\
\text { efficacy }\end{array}$ & $\begin{array}{l}\text { Social } \\
\text { influenc } \\
\text { e }\end{array}$ & $\begin{array}{l}\text { Online } \\
\text { shoppin } \\
\text { g }\end{array}$ & Career \\
\hline 2.653 & 2.671 & 2.251 & 1.536 & 2.073 & 2.292 & 3.108 \\
\hline
\end{tabular}

The results of the full collinearity VIF (FVIF) show that CMB is not a serious concern in this work as all the constructs have FVIF values below the recommended threshold of 3.3, hence all the constructs merit further analysis.

\section{Measurement Model Validation}

\section{RESULTS AND MODEL VALIDATION}

The validation of the measurement model involves the estimation of internal consistency reliability as well as the convergent and discriminant validity of the study constructs, which indicates the strength of the measures used to test the proposed model. Authors and researchers advice that measurement model in SEM must be evaluated and validated before assessing the structural model. This is to ensure that the measurement model are dependable and reliable as bad measurement model cannot be used to evaluate a structural model since this will produce spurious and unreliable results. 


\begin{tabular}{|c|c|c|c|c|c|c|c|c|c|c|}
\hline & Pr & pu & pe & ise & $\mathrm{si}$ & os & career & AVE & CB & CR \\
\hline pr1 & 0.693 & & & & & & & & & \\
\hline pr2 & 0.722 & & & & & & & & & \\
\hline pr3 & 0.944 & & & & & & & & & \\
\hline pr4 & 0.771 & & & & & & & 0.622 & 0.684 & 0.750 \\
\hline pu1 & & 0.712 & & & & & & & & \\
\hline pu2 & & 0.648 & & & & & & & & \\
\hline pu3 & & 0.701 & & & & & & & & \\
\hline pu4 & & 0.767 & & & & & & 0.502 & 0.687 & 0.710 \\
\hline pe2 & & & 0.829 & & & & & & & \\
\hline pe3 & & & 0.892 & & & & & 0.741 & 0.743 & 0.883 \\
\hline ise2 & & & & 0.834 & & & & & & \\
\hline ise4 & & & & 0.812 & & & & 0.677 & 0.682 & 0.871 \\
\hline si4 & & & & & 1 & & & 1 & 1 & 1 \\
\hline os1 & & & & & & 0.658 & & & & \\
\hline os2 & & & & & & 0.883 & & & & \\
\hline os3 & & & & & & 0.753 & & & & \\
\hline os 4 & & & & & & 0.903 & & 0.649 & 0.685 & 0.761 \\
\hline career1 & & & & & & & 0.819 & & & \\
\hline career4 & & & & & & & 0.894 & 0.735 & 0.748 & 0.882 \\
\hline
\end{tabular}

Notes: $P$ values for item loadings are significant at $<0.05$.

The properties of the construct show the Cronbach's Alpha, composite reliability and the average variance extracted (AVE), as well as items loadings (Table 4.1). Cronbach's alpha addresses the question of whether the indicators for latent variables display convergent validity and hence display reliability. By convention, the same cutoffs apply: greater or equal to .80 for a good scale, .70 for an acceptable scale, and .60 for a scale for exploratory purposes. All our constructs fall within good to acceptable scale. AVE reflects the average communality for each latent factor in a model, and should be greater than .5. AVE is used as a test of both convergent and divergent validity. All our constructs are well above 0.5 hence our scale has both convergent and divergent validity. Composite reliability measures internal consistency and all our constructs are well above the recommended level of 0.7 , which show adequate and satisfactory consistency.

Table 2a: Discriminant validity (Fornell Larcker criterion)

$\begin{array}{llllllll} & \text { Pr } & \text { pu } & \text { pe } & \text { Ise } & \text { si } & \text { os } & \text { ca } \\ \text { Perceived risk } & \mathbf{0 . 6 4 7} & & & & & & \\ \text { Perceived usefulness } & 0.362 & \mathbf{0 . 6 5 8} & & & & & \\ \text { Performance } & & & & & & & \\ \text { expectancy } & 0.418 & 0.077 & \mathbf{0 . 8 9 2} & & & & \\ \text { Internet self-efficacy } & 0.094 & 0.294 & 0.295 & \mathbf{0 . 8 4 0} & & & \\ \text { Social influence } & 0.218 & 0.058 & 0.466 & 0.018 & \mathbf{0 . 8 6 6} & & \\ \text { Online shopping } & 0.343 & 0.366 & 0.268 & 0.172 & 0.420 & \mathbf{0 . 6 9 8} & \\ & & & & - & - & - & \\ \text { Career } & 0.449 & 0.246 & 0.324 & 0.580 & 0.240 & 0.260 & \mathbf{0 . 8 9 4}\end{array}$


Okeke, T. C., Omodafe, P. U., Ezeh, G. A., \& Nwatu, B. C. (2020). Moderating Effect of Career on Women Online Shopping Behaviour in South-South, Nigeria. Archives of Business Research, 8(5). 143-164.

\section{Table 2b: HTMT Ratios}

(good if $<0.90$, best if $<0.85$ )

Perceived risk

$\begin{array}{llllll}\mathrm{Pr} & \mathrm{Pu} & \text { pe } & \text { ise } & \text { si } & \text { os }\end{array}$

Perceived usefulness $\quad 0.629$

Performance

$\begin{array}{lll}\text { expectancy } & 0.161 & 0.638\end{array}$

Internet self-efficacy $\quad 0.022 \quad 0.599 \quad 0.848$

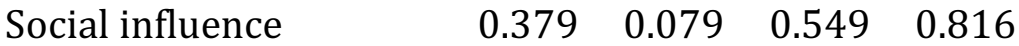

$\begin{array}{lllllll}\text { Online shopping } & 0.267 & 0.349 & 0.14 & 0.389 & 0.845\end{array}$

Career

$\begin{array}{llllll}0.073 & 0.574 & 0.492 & 0.276 & 0.564 & 0.678\end{array}$

Table 3: Model fit summary indices

\begin{tabular}{l|l|l|l} 
Model fit & PLS-SEM value & Threshold & Remark \\
\hline $\mathrm{R}^{2}$ Coefficient of Determination & 0.749 & 0.25 & Good fit \\
Average block VIF (AVIF) & 3.077 & $\leq 5$ & Good fit \\
Average full collinearity VIF (AFVIF) & 2.357 & $\leq 3.3$ & Good fit \\
Sympson's paradox ratio (SPR) & 1.000 & $\geq 0.7$ & Good fit \\
R-squared contribution ratio (RSCR) & 1.000 & $\geq 0.9$ & Good fit \\
Statistical suppression ratio (SSR) & 1.000 & $\geq 0.7$ & Acceptable \\
Nonlinear bivariate causality direction & 0.700 & $\geq 0.7$ & Acceptable \\
ratio (NLBCDR) & 0.888 & 0.80 & Good fit \\
Q-squared coefficients & 0.269 & $\geq 0.1$ & Acceptable \\
Tenenhaus GoF (GoF) & 0.026 & $\geq 0.25 \geq 0.36$ & Acceptable \\
Standardized root mean squared residual & 0.058 & $\leq 0.1$ & Acceptable \\
(SRMR) & $6.664(\mathrm{p}=0.001)$ & $\leq 0.1$ & Acceptable \\
Standardized mean absolute residual & & $\mathrm{p} \leq 0.05$ & \\
(SMAR) & & & \\
Standardized chi-squared (SChS) & & &
\end{tabular}

Table $2 \mathrm{~b}$ illustrates the discriminant validity of the constructs using the Fornell-Larcker Criterion, with correlation among constructs and the square root of AVE on the diagonal. All values in the diagonal were greater than those in the corresponding rows meaning that all measurement load more highly on their constructs than on other constructs. In view of this we can conclude that online shopping among career women is fully and sufficiently explained by the displayed latent variables' structure (convergent validity) and that this structure includes all unique manifest variables (discriminant validity). Although examination of cross-loadings and use of the FornellLarcker criterion are accepted methods for assessing the discriminant validity of a PLS model, these methods have shortcomings (Garson, 2016). We also used the Heterotrait-monotrait (HTMT) ratios to assess discriminant validity. Based on the threshold of Kock (2020) all the HTMT ratios fall within acceptable and good range. This is a further confirmation that our data has discriminant validity hence we assess the structural model. 


\section{Model fit and quality indices}

In addition to measurement model validation, model fit and quality indices were equally validated. We utilised the PLS-SEM in validating the research model and the quality indices that are most applicable are the $\mathrm{R}^{2}$ and the $\mathrm{Q}^{2}$ coefficients. After blindfolding, some items with poor loadings were removed and the $\mathrm{R}^{2}$ improved slightly from 0.715 to 0.721 which is an indication that we were right in removing those items. And when the moderating variable was added to the model the $\mathrm{R}^{2}$ improved to 0.749 which is an indication that the moderation was necessary and right. All the $\mathrm{R}^{2}$ values were well above the threshold table in 4.3 . The $\mathrm{Q}^{2}$ is the Jackknife equivalent of the $\mathrm{R}^{2}$ statistic (Duarte \& Raposo, 2010) and the coefficient is well above the threshold which means that our model has predictive relevance. WarpPLS SEM software was used to validate our research model which merges the precision of CB-SEM common factor model assumptions with the nonparametric characteristics of classic PLS; hence all the model quality and fit indices met the established threshold and the criteria (Kock, 2020).

\section{Structural model validation}

The main objective of this study is to examine the moderating effect of career on online shopping adoption of women. In validating the structural model as is normal with PLS-SEM, we rely on R2 which reflects the percent of variations in the DV that is accounted for by the IVs variables hypothesized to affect it; and the Q2 which shows the predictive relevance of our model as already discussed (table 3). Also used in assessing the model are path coefficients that make up the inner model measure the effect of IVs on the DV, the effect sizes, $p$-values, and t-values. Table 4 show the direct and the moderation/interaction effects in the first segment and moderating effect on the second segment, all of which are now used to validate the hypotheses formulated for the study.

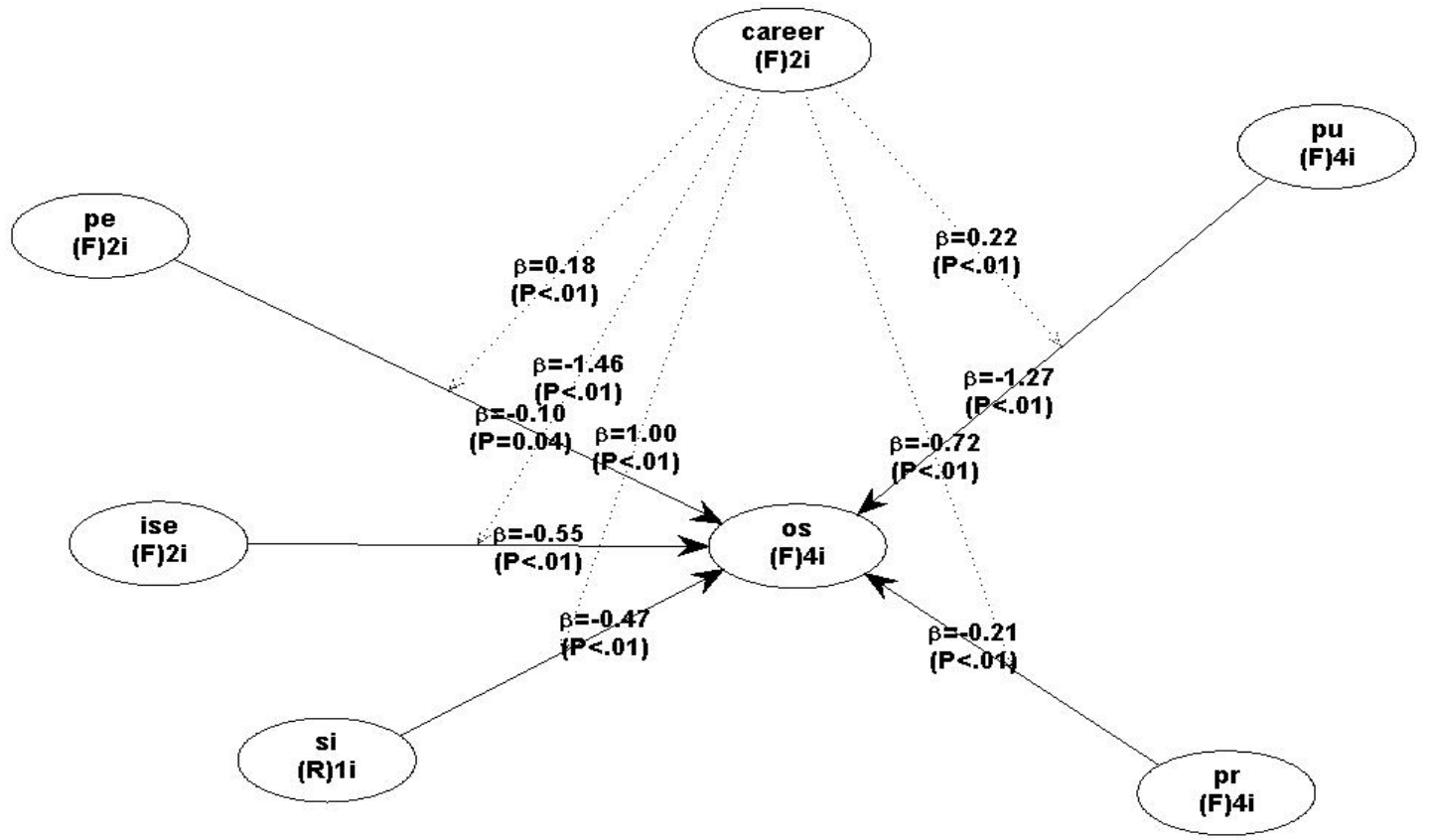

Figure 1: The research structural model 
Okeke, T. C., Omodafe, P. U., Ezeh, G. A., \& Nwatu, B. C. (2020). Moderating Effect of Career on Women Online Shopping Behaviour in South-South, Nigeria. Archives of Business Research, 8(5). 143-164.

\section{Table 4: Assessment of the structural model}

\begin{tabular}{l|l|l|l|l|l|l}
\hline Paths & Coefficients & $\begin{array}{l}\text { Effect } \\
\text { sizes }\end{array}$ & SE & $\begin{array}{l}\text { t- } \\
\text { values }\end{array}$ & $\begin{array}{l}\text { p- } \\
\text { values }\end{array}$ & Decision \\
\hline ISE -> OS & 0.547 & 0.113 & 0.052 & 10.534 & $<0.001$ & Supported \\
PE -> OS & 0.097 & 0.081 & 0.056 & 1.732 & 0.042 & Supported \\
PR -> OS & 0.214 & 0.080 & 0.055 & 3.912 & $<0.001$ & Supported \\
PU -> OS & 1.275 & 0.974 & 0.046 & 27.463 & $<0.001$ & Supported \\
SI -> OS & 0.467 & 0.325 & 0.053 & 8.884 & $<0.001$ & Supported \\
Career*ISE -> OS & 1.457 & 0.537 & 0.045 & 32.276 & $<0.001$ & Supported \\
Career*PE -> OS & 0.177 & 0.128 & 0.055 & 3.232 & $<0.001$ & Supported \\
Career*PR -> OS & 0.718 & 0.505 & 0.051 & 14.203 & $<0.001$ & Supported \\
& 0.218 & 0.061 & 0.055 & 3.993 & $<0.001$ & Not \\
Career*PU -> OS & & & & & & Supported \\
Career*SI -> OS & 1.001 & 0.423 & 0.048 & 20.691 & $<0.001$ & Supported \\
\hline
\end{tabular}

All the hypothesised relationships are statistically significant (Table 4). The part PR to OS bears ( $\beta$ $=0.214 ; \mathrm{t}$-value $=3.912, \rho=<0.000)$. This results validates H1a. In terms of interaction, the coefficient increased substantially as $\mathrm{PR}^{*}$ Career to OS shows $(\beta=0.718$; $\mathrm{t}$-value $=14.203 ; \rho=$ $<0.002)$. Based on this hypothesis $\mathrm{H} 1 \mathrm{~b}$ is also validated. The part PU to OS $(\beta=1.275$; $\mathrm{t}$-value $=$ 27.463 and $\rho=<0.001$ ). Based on this $\mathrm{H} 2 \mathrm{a}$ is accepted. However, part: $\mathrm{PU}^{*}$ Career to OS indicates $(\beta=0.218$; $\mathrm{t}$-value $=3.993$; and $\rho=<0.000$ ). The evidence here is not sufficient to validate $\mathrm{H} 2 \mathrm{~b}$ since the coefficient declined from 1.275 to just 0.218 . Also the effect size moved from 0.974 to 0.061 , hence the interaction drastically mulled the effect size. PE to OS has $(\beta=0.097$; $\mathrm{t}$-value $=$ 1.732; and $\rho=<0.000$ ). This evidence supports H3a and since the p-value is less than the 0.05 margin of error. Similarly, PE*Career to OS has $(\beta=0.177$; t-value $=3.232$; and $\rho=<0.000)$. Based on this, $\mathrm{H} 3 \mathrm{~b}$ is confirmed. The path from ISE to OS has $(\beta=0.547$; $\mathrm{t}$-value $=10.537$; and $\rho=<0.001)$; and based on this evidence, H4a is validated. Similarly, the path from ISE*Career to OS has $(\beta=$ 1.457; $\mathrm{t}$-value $=32.276$; and $\rho=<0.001$ ) thus $\mathrm{H} 4 \mathrm{~b}$ is validated. For social influence, the path from SI to OS has ( $\beta=0.467$; $\mathrm{t}$-value $=8.884$; and $\rho=<0.001)$; this evidence is very strong in support of H5a. Also the path from SI ${ }^{*}$ Career to OS has $(\beta=1.001$; $\mathrm{t}$-value $=20.691$; and $\rho=<0.001)$. Based on this evidence $\mathrm{H} 5 \mathrm{~b}$ is accepted.

The effect sizes are the absolute values of the individual contributions of the corresponding latent IVs to the R-squared coefficients of the DV. With this we ascertain whether the effects indicated by path coefficients are small, medium, or large. The values usually recommended are $0.02,0.15$, and 0.35; respectively (Cohen, 1988). Values below 0.02 suggest effects that are too weak to be considered relevant, even when the corresponding P values are statistically significant. The Effect sizes in our analysis shown in Table 4.4 (column 3) range from as high as 0.974 for PU to 0.061 for Career*PU, hence all the IVs in our analysis range from medium to high effect sizes and are all considered relevant in our model.

\section{CONCLUSIONS AND RECOMMENDATIONS/IMPLICATIONS}

The aim of this study was to evaluate the moderating effects of career on the online shopping behaviour of women in South-South Nigeria. The variables and constructs used in the study are perceived risk, perceived usefulness, internet self-efficacy, social influence, and performance expectancy with career as the moderating variable. The study was based on 330 valid responses 
collected from career women in the six states that make up the South-South zone of Nigeria. Online shopping behaviour (OS) of the career women was the response variable. All variables both the IVs, DV and moderator were measured with four items each. WarpPLS 7.0 software utilized in analyzing the data and the analyses show that all the five IVs except one are statistically significant at $p<0.000$ while one was significant at $p<0.05$. This means that all the IVs studied determine online shopping behaviour of women in South-South Nigeria. Accordingly the career women in that geopolitical zone of Nigeria value the usefulness and the import of shopping online as opposed to visiting physical store since they are highly involved with their various careers.

Career moderates all the IVs except PU which show higher coefficient without moderation. Thus the career women in spite of the risks associated with online shopping still perceive internet shopping as useful. We also ascertained the predictive relevance of the IVs and our analyses show that PU has the highest predictive power of 0.974 while the interaction between career and PU show the least predictive ability of 0.061 . However all the constructs show medium to high predictive ability based on the threshold and instruction of Cohen (1988). This finding agrees with Hirst and Omar (2007) which shows that women who shop for apparel online are aware of some of the discouraging features of online shopping, but these features do not deter them from buying online. Thus career women enjoy the convenience of online shopping despite the risks involved. On social influence, our study agrees with Mazman, et al, (2009) that females compared to men are more likely to adopt technological innovation through social influence rather than by a personal decision whereas in case of males. This study also found out that internet self-efficacy influence women's online shopping and that career moderates this influence. This is in line with Celik (2015) observation that females tend to feel less comfortable with computing because they react more somatically to emotion and uncertainty; and thus are more reluctant to develop adequate computing self-efficiency. This implies therefore that with career women concerns on computing will be addressed since this is to enhance their dual roles as managers of the family which is combined with stress of office and career.

Based on the findings of this study we recommend, since PU significantly affects women online shopping, that online shoppers should try to make their websites appealing and memorable for any visitor/shopper so as to enhance repeat buying. This is more important as our study goes to show that the typical $21^{\text {st }}$ century career woman seems to appreciate convenience, pleasure and perceived time value more than thriftiness and bargaining that leads to more stress and workfamily conflict especially in the developing-country context. With career having a moderating effect on online shopping adoption by career women, the study hereby recommends that continuous patronage of online shops by career women would be guaranteed with improvements in online shopping environments with enjoyable virtual experience/pleasure; in order to attract other working women thereby increasing high traffic to the websites. Additionally, the study recommends further development in the online setting technology in the creation and design of female-friendly websites to enable greater use of virtual reality and interaction between consumers and providers, which is more likely to enhance the "shopping experience" for career women in Nigeria., 
Okeke, T. C., Omodafe, P. U., Ezeh, G. A., \& Nwatu, B. C. (2020). Moderating Effect of Career on Women Online Shopping Behaviour in South-South, Nigeria. Archives of Business Research, 8(5). 143-164.

\section{References}

Aghdaie, S. F., Piraman, A. \& Fathi, S. (2011). An analysis of factors affecting the consumer's attitude of trust and their impact on internet purchasing behaviour. International Journal of Business and Social Science, 2(4),147-158.

Ahmed, E. K. (2012). Consumer behavior differences between developed and developing Countries. Retrieved from, we are development Website: http://wearedevelopment.net/2011/11/01/10-consumer-behavior differences-betweendeveloped-and developing-countries/Retrieved on March 7, 2018.

Ajayi, F., Ojo, S. \& Mordi, C. (2015). Work-family balance and coping strategies among women: Evidence from Commercial Banks in Nigeria. European Journal of Business and Management www.iiste.org ISSN 2222-1905

(Paper) ISSN 2222-2839 (Online) Vol.7(2).

Ajzen, I. (1991). The theory of planned behavior. Organizational behavior and human decision processes, 50(2), 179211.

Akaah, I. P. (1989). Differences in research Ethics judgments between male and female marketing professionals. Journal of Business Ethics 8(3), 375-381.

Alanana, O. (2004). Women and national development. Journal of Social and Management Sciences, Delta State University, Abraka. 1(1).

Bandura, A. (1986), Social Foundation of Thought and Action: A Social-Cognitive View. Englewood Cliffs, Prentice Hall.

Bartel-Sheehan, K. (1999). An investigation of gender difference in online privacy concerns and resultant behaviours. Journal of Interactive Marketing. 13(4), 30-65.

Benco, C. \& Pelster, B. (2013). How women decide. Harvard Business Review (HBR) on Gender. September 2013 issue. Retrieved from https://www.google.com.ng/?ion=1\&espv=2\#q=Benc./nb band+Pelster+(2013). Assessed on 23 ${ }^{\text {rd }}$ July, 2017.

Bhatnagar, A. \& Ghose, S. (2004a). A Latent Class Segmentation Analysis of E-Shoppers," Journal of Business Research $57,758-767$.

Bhatnagar, A., Misra, S. and Rao, H. R., (2000), On Risk, Convenience, and Internet Shopping Behavior," Communications of the ACM, 43(11), 98-105.

Busch, T. (1995). Gender differences in self-efficacy and attitudes toward computers. Journal of Educational Computing Research,12(2), 147-158.

Carrigan, M. \& Szmigin, I. (2006). Mothers of invention: Maternal empowerment and convenience consumption. European Journal of Marketing. 40(9/10), 1122-1142.

Catalyst, 0. (2007). The double-bind dilemma for women in leadership Damned if you do, doomed if you don't? New York, NY: Catalyst Publication. Retrieved from http://www.catalyst.org on22 ${ }^{\text {nd }}$, August, 2017.

Celik, H. (2015). Influence of social norms, perceived playfulness and online shopping anxiety on customers' adoption of online retail shopping: an empirical study in the Turkish context. International Journal of Retail \& Distribution Management, (398) No. 6,pp. 390-413.

Celik, H. (2016). Customer online shopping anxiety within the Unified Theory of Acceptance and Use Technology (UTAUT) framework. Asia Pacific Journal of Marketing and Logistics, 28(2), 278-307, https://doi.org/10.1108/APJML-05-2015-0077.

Cheng, L.D., Gillenson, M. L. \& Sherrell, D.L. (2002). Enticing Online Consumers: An Extended Technology Acceptance Perspective. Information \& Management. 39( 8), 705-719.

Christ, C. (2004). Inside the Clockwork of Women's Careers. Speech to the European Professional Women's Network. Paris: September, 21.

Citrin, A. V., Sprott, D.E., Silverman, S.N. \& Stem Jr, D.E. (2000). Adoption of Internet Shopping: the Role of Consumer Innovativeness. Industrial Management \& Data Systems 100(7), 294-301. 
Coen-Pirani, D. \& León, A. \& Lugauer, S. (2010). The effect of household Appliances on Female Labour Force Participation: Evidence from Microdata," Labour Economics, Elsevier, 17(3), 503-513.

Davis, F.D (1989). Perceived usefulness, perceived ease of use and user acceptance of information technology. MIS Quarterly,13(3), 319-340.

Duarte, P.A.O., Raposo, M.L.B. (2010), A PLS Model to Study Brand Preference: An Application to the Mobile Phone Market, in Esposito Vinzi, V., Chin, W.W., Henseler J. and Wang, H. (Eds), Handbook of Partial Least Squares: Concepts, Methods and Applications (Springer Handbooks of Computational Statistics Series), Springer, Heidelberg, Dordrecht, London, New York, NY, Vol. II, pp. 171-193

Eastin, M. S., \& LaRose, R. (2000). Internet self-efficacy and the psychology of the digital divide. Journal of Computer Mediated Communication, 6(1). Retrieved March, 18, 2017, from http://icmc.indiana.edu/vol6/issue1/.

Eastin, M.S. (2002), "Diffusion of e-commerce: an analysis of the adoption of four e-commerce activities", Telematics and Informatics, (19)3, 251-67.

Eze, N. (2017). Balancing Career and Family: The Nigerian Woman's Experience. Retrieved online: http://scholarworks.waldenu.edu/dissertations. Accessed on $20^{\text {th }}$ April, 2017,

Ezzedeen, S. R. \& Ritchey, K.G. (2009). Career advancement and family balance strategies of executive women. Gender in Management: An International Journal, 24(6), 388-411.

Fakeye, Y., George, O. J., \& Owoyemi, O. (2012). Women in purgatory: The case of Nigerian women in the boardrooms. Asian Journal of Business \& Management Sciences, 1(10), 134-150. Retrieved from http://www.ajbms.org/articlepdf/AJBMS20121914

Fornell, C., \& Larcker, D. F. (1981). Evaluating structural equation models with unobservable variables and measurement error. Journal of Marketing Research,18(1),39-50. https://doi.org/10.2307/3151312.

Forsythe, S.M. \& Shi, B. (2003). Consumer patronage and risk perceptions in internet shopping. Journal of Business Research, 56(1),867-875.

Gabriel, J.M.O, Ogbuigwe, T. D. \& Ahiauzu, L. U. (2016). Online Shopping Systems in Nigeria: Evolution, Trend and Prospects. Asian Research Journal of Arts \& Social Sciences. 1(4),1-7.

Garbarino, E., \& Strahilevitz, M. (2004). Gender differences in the perceived risk of buying online and the effects of receiving a site recommendation. Journal of Business Research, 57, 768-775. http://dx.doi.org/10.1016/S01482963(02)00363-6.

Garson, G.D. (2016). Partial least squares: regression and structural equation models. Glenn Drive Asheboro, NC 27205 USA: Statistical Publishing Associates. E-book.

Goswami, A. \& Dutta, S. (2016). Gender Differences in Technology Usage-A Literature Review. Open Journal of Business and Management, 4, 51-59. http://dx.doi.org/10.4236/ojbm.2016.41006. Accessed on July, 20, 2017.

Greenhaus, J.H. \& Powell, G.N. (2006). When work and family are allies: a theory of work-family enrichment. Academy of Management Review, 31(1),72-92.

Hair, J. F., Risher, J. J., Sarstedt, M., \& Ringle, C. M. (2019). When to use and how to report the results of PLS-SEM. European Business Review, 31(1), 2-24.

He, J. \& Freeman, L. (2010). Are men more technology-oriented than women? The role of gender on the development of general computer self-efficacy of college students. Journal of Information Systems Education, 21(2), 203-212.

Hernandez B. Jimenez J. \&Martin M. (2009). Adoption vs Acceptance of E-commerce: $\quad$ Two different decisions. European Journal of Marketing. 43(9/10),1232-1245. DOI: 1108/03090560910976465

Hewlett, S. A. (2002). Executive women and the myth of having it all. Harvard-Business Review (HBR) on Gender. April 2002 issue. Retrieved from https://hbr.org/2002/04/executive-women-and-the-myth-of-having-it-all on 10 ${ }^{\text {th }}$ April, 2017.

Hirst, A. \& Omar, O. (2007), Assessing Women's Apparel Shopping Behaviour on the Internet, Journal of Retail Marketing Management Research, 1(1), October, ISSN 1752-6183 print / 1752-6191 online, pp. 32-40. 
Okeke, T. C., Omodafe, P. U., Ezeh, G. A., \& Nwatu, B. C. (2020). Moderating Effect of Career on Women Online Shopping Behaviour in South-South, Nigeria. Archives of Business Research, 8(5). 143-164.

Howcroft, D. \& Wilson, M. (2003), Participation: 'Bounded freedom' or hidden constraints on user Involvement, New Technology, Work and Employment, 18(1), 2-19.

Ibrahim T.I \& Roni, S.M. (2017), Partial Least Square Approach to Second Order Factor in Behavioural Study of Accounting Information System, SHS Web of Conferences 36, 00032 (2017). Pp.1-7.

Idemobi, E.I. \& Akam, U.G. (2012). Managing Work-life conflicts in Public Organizations: Experience from a public sector organization in Nigeria. Nigerian Academy of Management Journal. 6(1).

Internet World Stats (2017). Retrieved from - www.internetworldstats.com. Accessed online on April, 2018.

Jakobsen, M. (2015). Common Method Bias in Public Management Studies, International Public Management Journal, DOI: $10.1080 / 10967494.2014 .997906$

Kim, H. \& Song, J.(2010). The Quality of Word-of Mouth in the Online Shopping Mall. Journal of Research in Interactive Marketing, 4(4), 376- 390.

Koch, N. (2020), WarpPLS user manual: version 7.0, ScriptWarp Systems, Laredo, Texas, USA. Online Edition. Downloaded from: www.scriptwarp.com. Assessed on April 12, 2020.

Kolodinsky J.M., Hogarth, J.M.; \& Hilgert, M.A. (2004). "The adoption of electronic banking technologies by US consumers", The International Journal of Bank Marketing (22: 4/5), 238-359.

Kotler, P. \& Keller, K. L. (2016). Marketing Management - A Global edition. London: Pearson Education Inc. $15^{\text {th }}$ ed.

Lachance, M., Beaudoin, P. \& Robitaille, J. (2003), Adolescents' Brand Sensitivity in Apparel: Influence of Three Socialization Agents, International Journal Consumer Studies, 27, 47-57.

Liebermann Y. \& Stashevsky S. (2002). Perceived Risks as Barriers to Internet and E-commerce Usage. Qualitative Market Research; 5(2),291-300.

Lussier, R. N. (2006). Management Fundamentals: Concepts, Applications and Skill development. Mason, (3rd ed.) USA: Thomson.

Makgosa, R. \& Mohube, K. (2007), Peer influence on young adults' product purchase decisions, African Journal of Business management, 1(3), 64-71.

Mazman, S.G., Usluel, Y.K., \& Cevik, V. (2009), Socisl Process in the Adoption and Usage of Innovation: Gender Differences, World Academy of Science, Engineering and Technology, 3, 31-34.

Monsuwe T. P, Dellaert B \& Ruyter K. (2004). What drives consumers to shop online: A literature review. International Journal of Service Industry Management, 15(1), 102-121.

Mackenzie, S.B. \& Podsakoff, P.M. (2012), Common Method Bias in Marketing: Causes, Mechanisms, and Procedural Remedies, Journal of Retailing 88(4), 542-555.

Mordi, C. Simpson, R., Singh. S., \& Okafor, C. (2010). The Role of Cultural Values in understanding the Challenges faced By Female Entrepreneurs in Nigeria. Gender in Management: An International Journal, 25 (1), 5-21.

Narasimhamurthy, N. (2014). Cultural Impact and Gender on Indian Young Adults in Using Social Networking Sites. International Journal of Interdisciplinary and Multidisciplinary Studies (IJIMS), 1, 113-125.

National Bureau of Statistics (2015). Statistical Report on Women and Men in Nigeria. Accessed online on 12 Nov, 2017.

Nicholas, S.Y. \& Fox, K.D (1983). Buying Time and Saving Time: Strategies for Managing Household Production. Journal of Consumer Research.10. 197-208.

Nielsen, U. (2010). Global Trends in Online Shopping: A Nielsen Global Consumer Report. June, 2010.

Nkamnebe, A.D. (2017). From Mortar-and-Brick to Online Shops: A Paradigm Shift in the Africa's Retailing Landscape; in Management Sciences in the Nigeria's Quest for Development, ( $1^{\text {st }}$ ed), Awka: Scoa Heritage Nigeria..

Obamiro, J. K., \& Obasan, K. (2013). Glass ceiling and women career advancement: Evidence from Nigerian construction Industry. Iranian Journal of Management Studies,679-99.Retrievedfrom https://ijms.ut.ac.ir/pdf 30125 dfcc031c2e5cf5c2c1d2b94826dc7128.html 
Odiaka, N.O (2013). The concept of gender justice and women's rights in Nigeria: Addressing the missing link. Journal of Sustainable Development Law and Policy, 2(1).

Ogbogu, C.O. (2013). Work-Family Role Conflict among Academic Women in Nigerian Public Universities. WEI International Academic Conference Proceedings Orlando, USA. The West East Institute 19. Retrieved online from https://www.westeastinstitute.com/wp-content/uploads/2013/04/ORL13-158 on March 31, 2017.

Okeke, O. J. (2017). Nigerian culture: a Barrier to the Career Progress of Women in Nigeria. Global Journal of Human Resource Management 5(5), 1-11, June 2017, Published by European Centre for Research Training and Development UK (www.eajournals.org)-(Online) .

Okeke, T.C. \& Nkamnebe, A.D. (2018), The Mediating Role of Perceived Trust on Consumer Adoption of Point of Sale (POS) e-Payment System in Awka, Anambra State, Nigerian Academy of Management Journal, 13(1).

Oniye, A.O (2008). Women Education: Problems and Implications for Family Responsibility. The Nigerian Journal of Guidance and Counselling, 9(1) 2008. Available at Www.Unilorin.Edu.Ng/Unilorin/Publication

Osakwe, C.N (2019), Understanding customer-perceived quality in informal stores, Journal of Services Marketing, 33(2), 133-147. https://doi.org/10.1108/JSM-05-2018-0162

Pavlou, P.A. (2003). Consumer acceptance of electronic commerce: Integrating trust and risk with the technology acceptance model". International Journal of Electronic Commerce, 7(3), 101-123.

Pereay Monsuwé, T., Dellaert, B.G.C. \& de Ruyter, K. (2004). What drives consumers to shop online? A literature review. International Journal of Service Industry Management, 15(1), 102-121.

Podsakoff, P.M., MacKenzie, S.B., Podsakoff, P.M., Lee, Jeong-Leon, \& Podsakoff, N.P. (2003),“Common Method Biases in Behavioral Research: A Critical Review of the Literature and Recommended Remedies," Journal of Applied Psychology, 88 (5),879-903.

Rogers, E. M. (2003). Diffusion of Innovations New, (5th ed), York: The Free Press.

Seema A. \& Sujatha S. (2018). Perceived organisational support from:https://www.researchgate.net/publication/316290459.Perceived organiational support on career success an employee perspective - an empirical study from an Indian context [accessed Apr 10, 2017].

Setiffi, F. (2014), Becoming Consumers: Socialization into the World of Goods, Italian Journal of Sociology of Education, 6(3), 6-25, Assessed from: http://www.ijse.eu/wp-content/uploads/2004/10/2014_3_2.pdf. on 22 ${ }^{\text {nd }}$ April, 2020.

Shagaya, S. (2013). How we made it in Africa, on 'What Products are Nigerians Buying Online? Sim Shagaya, CEO of Konga, Africa Business Insight.

Shove, E. (2003). Comfort, Cleanliness and Convenience: The Social Organization of Normality. Berg. Accessed August $23,2017$.

Silverstein, M. J. \& Sayre, K. (2009). The female economy. Harvard Business Review (HBR) on Gender. September2009 Issue. Retrieved from https://hbr.org/2009/09/the-female-economy on 23 ${ }^{\text {rd }}$ April, 2018.

Slide, C. (2017). Career advice for women looking for work-life balance. Retrieved from 5https://www.moneycraphers.com/career-advice-women/.

Telecommunication Development Bureau-TDB. (2015). Measuring the information society report, International telecommunication Unit, ISBN978-92-61-15791-3/REP.

The Economist (2013). E-commerce in China: The Alibaba phenomenon. The Economist Magazine, March 23, 2013(http://www.economist.com/news/leaders/21573981).

Torkzadeh, G., \& Van-Dyke, T. P. (2002). Effects of training on internet self-efficacy and computer user attitudes. Computers in Human Behavior, 18(5), 479-494.

Ugwu, J.N, Maduagwu, E.N \& Aginah, C. (2016). Gender Stereotyping and Career Advancement of Female Managers in Nigerian public and private firms: A Comparative Study (A study of selected firms in Enugu State). Advance Research Journal of Multi-disciplinary Discoveries 10(1), 48-54. 
Okeke, T. C., Omodafe, P. U., Ezeh, G. A., \& Nwatu, B. C. (2020). Moderating Effect of Career on Women Online Shopping Behaviour in South-South, Nigeria. Archives of Business Research, 8(5). 143-164.

Venkatesh, V., \& Davis, F.D. (2000). A theoretical extension of the technology acceptance model: Four longitudinal field studies. Management Science, 4(6) 186-204.

Venkatesh, V., Morris, M. G., Davis, G.B., \& Davis, F.D. (2003). “User Acceptance of Information Technology: Toward a Unified View," MIS Quarterly (27)3, 425-478.

Venkatesh, V., Thong, J.Y.L. \& Xu, X. (2012). Consumer acceptance and use of information technology: Extending the unified theory of acceptance and use of technology. MIS Quarterly, 36(1), 157-178.

Wangpipatwong, T. \& Papasratorn, B. (2007), The Influence of constructivist e-learning system on Student learning outcomes, International Journal of Information Technology Education, 3(4), 21-33.

World Population Report (WPR)(2018), World Population Report 2018, Assessed from https://www.unfpa.org.

Zhou, L., Dai, L. and Zhang, D. (2007). Online Shopping Acceptance Model - A Critical Survey of Consumer Factors in Online Shopping. Journal of Electronic Commerce/Research, 8(1), 29-54. 